\title{
Lipogenesis in situ in the Genetically Obese Zucker Fatty Rat (fa/fa): Role of Hyperphagia and Hyperinsulinaemia
}

\author{
V. Godbole and D. A. York \\ Department of Nutrition, School of Biochemical and Physiological Sciences, Southampton University, Southampton, England
}

\begin{abstract}
Summary. In situ fatty acid synthesis has been measured with ${ }^{3} \mathrm{H}_{2} \mathrm{O}$ in anaesthetised lean and obese Zucker (fa/fa) rats. The accumulation of fatty acids was increased in both the liver and adipose tissue of young $\mathrm{fa} / \mathrm{fa}$ rats as a result of both an increased rate of lipogenesis and an increase in tissue mass. Whereas total hepatic lipogenesis increased with age, total adipose tissue lipogenesis decreased in older fa/ fa rats. Experiments with hepatectomized rats showed that the liver was the major site of the excess fatty acid synthesis in fa/fa rats. The enhanced rate of lipogenesis in $\mathrm{fa} / \mathrm{fa}$ rats was abolished by either pairfeeding or streptozotocin treatment. The results suggest that the increased fatty acid synthesis in $\mathrm{fa} / \mathrm{fa}$ rats is secondary to the hyperphagia, hpyerinsulinaemia, and increased mass of hepatic and adipose tissues.
\end{abstract}

Key words: Liver, adipose tissue, Zucker fatty rat, lipogenesis, pair-feeding, streptozotocin, insulin.

The genetically obese Zucker fatty rat (fa/fa) deposits excessive quantities of fat in both subcutaneous and intraperitoneal fat stores $[1,2]$. However, little is known of the relative importance of adipose tissue and liver in situ in the synthesis of this excess lipid. A number of lipogenic enzymes have increased activity in both the liver and adipose tissue of fa/fa rats fed ad libitum $[3,4,5]$, although food restriction reduces these activities towards normal $[3,6]$. From in vitro studies, adipose tissue lipogenesis is known to be elevated in young fa/fa rats [7] but normal in older $\mathrm{fa} / \mathrm{fa}$ rats when insulin resistance has increased [8]. Recent reports have suggested that hepatic lipogenesis may also be increased in fa/fa rats $[6,9]$.
Our studies using a ${ }^{3} \mathrm{H}_{2} \mathrm{O}$ marker and isolated hepatocytes have shown that the liver of fa/fa rats has a greatly increased capacity for fatty acid synthesis [10], but has a normal profile of substrate incorporation into fatty acids [11]. Hems et al [12] have shown from in situ studies that the adipose tissue is the major site of excess fatty acid synthesis in the obese $\mathrm{ob} / \mathrm{ob}$ mouse. This paper reports similar in situ studies on young (4-5 week) and older (13 week) fa/ fa rats.

\section{Material and Methods}

\section{Animals}

The female obese $(\mathrm{fa} / \mathrm{fa})$ rats and their lean littermates $(+/$ ? $)$ used in these studies were from the Southampton colony. All animals were housed at a constant temperature $\left(22^{\circ} \mathrm{C}\right)$ in a controlled lightdark cycle (0730-1930). Food was provided ad libitum except where stated in the text. In some experiments, fa/fa rats were pair-fed to the food intake of their lean littermates by providing each fa/ fa rat with the quantity of food eaten on the previous day by its lean littermate control. All pair-fed animals were fed from 0900 to $1300 \mathrm{~h}$ to prevent any complications that might have arisen from differences in feeding pattern. In these animals, lipogenesis was studied two hours after the beginning of the feeding period.

Diabetes was induced by IV injection of a freshly prepared solution of streptozotocin (a gift from Upjohn Co. Ltd) $65 \mathrm{mg} / \mathrm{kg}$ in citrate buffer, $(0.05$ $\mathrm{mol} / \mathrm{l}) \mathrm{pH}$ 4.3. Fatty acid synthesis was measured 8 days later. All streptozotocin-treated rats had a reduced rate of weight gain (Table 5) had glucose permanently present in the urine (Clinistix) and serum insulin was markedly reduced (see Table 5). 


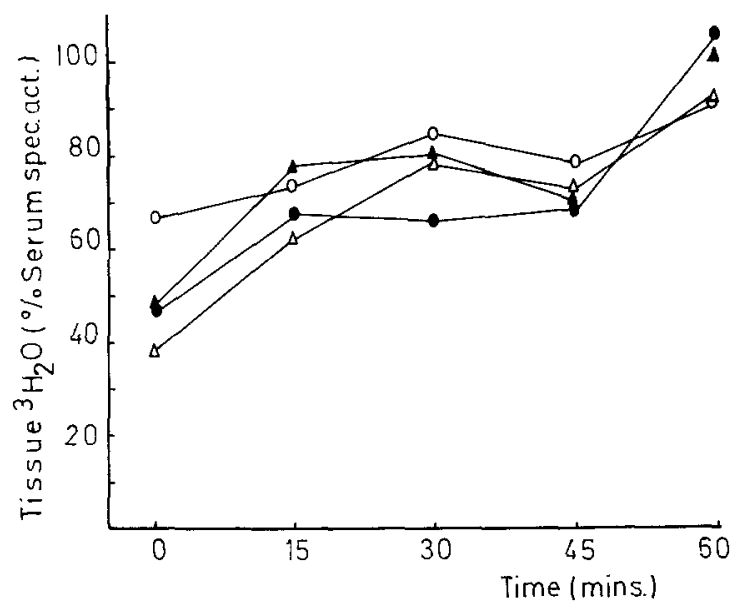

Fig. 1. The specific activity of tissue water after IV injection of ${ }^{3} \mathrm{H}_{2} \mathrm{O}$. The results are expressed as a percentage of serum specific activity. Duplicate samples of each tissue from a single animal were used at each point. Open symbols lean; solid symbols fa/fa; Liver $(O, \boldsymbol{O})$; and adipose tissue $(\triangle, \Delta)$. Perimetrial and subcutaneous fat depots gave very similar results and the figures for adipose tissue represent the mean of these two sites at each time

Table 1. Hepatic and adipose tissue lipogenesis in lean and obese $\mathrm{fa} / \mathrm{fa}$ rats fed ad libitum

\begin{tabular}{|c|c|c|c|c|c|}
\hline & \multirow[t]{2}{*}{$\begin{array}{l}\text { Age } \\
\text { (weeks) }\end{array}$} & \multicolumn{3}{|c|}{$\begin{array}{l}\text { Fatty acid synthesis } \\
(\mu \mathrm{mol} / \mathrm{g} \text { tissue/h) }\end{array}$} & \multirow{2}{*}{$\begin{array}{l}\text { Serum } \\
\text { insulin } \\
(\mu \mathrm{U} / \mathrm{ml})\end{array}$} \\
\hline & & Hepatic & P.M. ${ }^{\mathrm{a}}$ & S.C. ${ }^{a}$ & \\
\hline Lean & $\begin{array}{r}5 \\
13\end{array}$ & $\begin{array}{l}2.7 \pm 0.5 \\
4.8 \pm 0.5 \\
\mathrm{p}<0.05\end{array}$ & $\begin{array}{l}1.4 \pm 0.1 \\
1.2 \pm 0.4 \\
\text { N.S. }\end{array}$ & $\begin{array}{l}0.7 \pm 0.1 \\
1.1 \pm 0.3 \\
\text { N.S. }\end{array}$ & $\begin{array}{l}56 \pm 5 \\
67 \pm 5 \\
\text { N.S. }\end{array}$ \\
\hline $\mathrm{fa} / \mathrm{fa}$ & $\begin{array}{r}5 \\
13\end{array}$ & $\begin{array}{l}26.5 \pm 1.5^{c} \\
47.0 \pm 6.6^{c} \\
p<0.05\end{array}$ & $\begin{array}{c}10.6 \pm 1.1^{c} \\
2.1 \pm 0.2 \\
<0.001\end{array}$ & $\begin{array}{l}7.6 \pm 0.4 \\
1.0 \pm 0.1 \\
<0.001\end{array}$ & $\begin{array}{l}164 \pm 22^{b} \\
319 \pm 22^{c} \\
<0.01\end{array}$ \\
\hline
\end{tabular}

a P.M. - perimetrial fat pads; S.C. - subcutaneous fat pads. There were 6 animals in each group

b $\mathrm{p}<0.01$

c $\mathrm{p}<0.001$ compared to equivalent lean group

In some experiments, it was necessary to isolate the liver from the circulation. This was effected by ligaturing both the hepatic portal vein and hepatic artery [13]. Ligatures were placed around these vessels in control animals but not secured. Fatty acid synthesis was measured immediately after these operative procedures.

\section{Fatty Acid Synthesis}

The method of Lowenstein [14] utilizing the incorporation of ${ }^{3} \mathrm{H}_{2} \mathrm{O}$ into fatty acids was followed. Rats were anaesthetised with $60 \mathrm{mg} / \mathrm{kg}$ nembutal and remained anaesthetised throughout the experimental period. $4 \mathrm{mCi}^{3} \mathrm{H}_{2} \mathrm{O}$ in $9 \mathrm{~g} / 1$ saline (Radiochemical Centre, Amersham, England) was injected into the tail vein. After one hour, a blood sample was obtained by cardiac puncture for estimation of serum ${ }^{3} \mathrm{H}_{2} \mathrm{O}$ specific activity. The liver, perimetrial and hind limb subcutaneous fat pads were dissected free, weighed and then homogenized in chloroform: methanol $(2: 1, \mathrm{~V} / \mathrm{V})$ for extraction of lipids [15]. An aliquot of the lipid extract was saponified with 1.0 $\mathrm{mol} / 1 \mathrm{KOH}$ in $95 \%(\mathrm{~V} / \mathrm{V})$ methanol. After extraction of sterols, the lipid extract was acidified and fatty acids were then extracted into petroleum ether: ether $(1: 1, \mathrm{~V} / \mathrm{V})$. An aliquot of the fatty acid extract was evaporated to dryness in the presence of benzene: methanol $(1: 1, \mathrm{~V} / \mathrm{V})$, and radioactivity measured in a Philipps scintillation counter after addition of Tritoscint scintillation fluid. (Xylene, 21; Synperonic NXP 11 (Cargo fleet Chemical Co., Stockton on Tees), PPO $12 \mathrm{~g}$; dimethyl POPOP $0.9 \mathrm{~g}$ (KochLight)). The separative procedures were checked by thin layer chromatography. Serum lipids were separated and saponified by the same method, but all samples were then run on thin-layer chromatography before measurement of radioactivity.

\section{Specific Activity of Tissue Water}

Rats were sacrificed at varying times after injection of $4 \mathrm{mCi}^{3} \mathrm{H}_{2} \mathrm{O}$. Weighed samples of liver, perimetrial and hind limb subcutaneous fat were homogenized in saline $(0.15 \mathrm{~mol} / \mathrm{l})$. The aqueous extract was lyophilized, the water collected and ${ }^{3} \mathrm{H}$ content assayed by scintillation counting. A second sample of each tissue was dried at $90^{\circ} \mathrm{C}$ to ascertain total tissue water content from which the specific activity of tissue water was calculated. The half-life of serum triglyceride was measured after injection of Intralipid by the method described by Hems et al [12].

\section{Expression of Results}

The rates of fatty acid synthesis are expressed as $\mu \mathrm{mol}$ of fatty acid synthesized. This was calculated as

$\frac{d{ }^{3} \mathrm{H} \text { in fatty acid }}{\text { spec. act. }{ }^{3} \mathrm{H}_{2} \mathrm{O}(\mathrm{dpm} / \mu \mathrm{g} \text { atom } \mathrm{H}) \times 13.3} \quad[16,17]$.

Insulin was measured by a radioimmunoassay procedure (Radiochemical Centre, Amersham, England) utilizing a rat insulin standard (Novo Labs, Denmark). The assay was sensitive down to $6.25 \mu \mathrm{U} /$ $\mathrm{ml}$ and had a precision of $8 \%$ (standard error as percentage of mean value for 10 estimates of a single sample).

\section{Results}

The calculation of fatty acid synthesis after IV injection of ${ }^{3} \mathrm{H}_{2} \mathrm{O}$ assumes that the tissue water pool 
instantly attains the specific activity of serum water. Figure 1 shows that this assumption was not correct. After a very rapid initial exchange, tissue water of both the liver and adipose tissue only slowly approached the specific activity of serum. However, the time course for all three tissues in both animals was very similar. Hence, the qualitative interpretation of the results is valid although the quantitative values (calculated from the serum specific activity at 1 hour) will be artificially low.

The rates of fatty acid synthesis in liver and two adipose sites in lean and $\mathbf{f a} / \mathbf{f a}$ rats fed ad libitum are given in Table 1. At 5 weeks of age, the rate of fatty acid synthesis in all three tissues of fa/fa rats was approximately ten-fold greater than in the lean controls. With increasing age, the rates of hepatic fatty acid synthesis increased in lean mice while adipose tissue lipogenesis remained constant. In contrast,

Table 2. Total hepatic and adipose tissue lipogenesis in lean and obese fa/fa rats fed ad libitum

\begin{tabular}{|c|c|c|c|c|c|}
\hline & \multirow[t]{2}{*}{$\begin{array}{l}\text { Age } \\
\text { (weeks) }\end{array}$} & \multicolumn{4}{|c|}{$\begin{array}{l}\text { Total fatty acid synthesis } \\
(\mu \mathrm{mol} / \text { tissue } / \mathrm{h})\end{array}$} \\
\hline & & Hepatic & P. M. ${ }^{\mathrm{a}}$ & S. C. ${ }^{a}$ & $\mathrm{~L} / \mathrm{AT}^{\mathrm{b}}$ \\
\hline \multirow[t]{2}{*}{ Lean } & 5 & $12.7 \pm 4.4$ & $0.8 \pm 0.1$ & $0.9 \pm 0.2$ & 7.4 \\
\hline & 13 & $\begin{array}{l}39.8 \pm 11.9 \\
\text { p N.S. }\end{array}$ & $\begin{array}{l}3.2 \pm 0.7 \\
<0.05\end{array}$ & $\begin{array}{l}3.5 \pm 0.8 \\
<0.05\end{array}$ & 5.9 \\
\hline \multirow[t]{2}{*}{$\mathrm{fa} / \mathrm{fa}^{\mathrm{c}}$} & 5 & $221.0 \pm 58.0$ & $49.0 \pm 5.4$ & $64.1 \pm 2.5$ & 2.0 \\
\hline & 13 & $\begin{array}{l}618.0 \pm 100.0 \\
p<0.01\end{array}$ & $\begin{array}{l}24.0 \pm 1.8 \\
<0.001\end{array}$ & $\begin{array}{l}32.7 \pm 5.5 \\
<0.001\end{array}$ & 10.8 \\
\hline
\end{tabular}

a P.M. - perimetrial fat pads; S.C. - subcutaneous fat pads

$b$ L/AT Ratio of total lipogenesis in liver and adipose tissue calculated from

Hepatic fatty acid synthesis

P.M. + S.C. fatty acid synthesis

c All results for $\mathrm{fa} / \mathrm{fa}$ rats were significantly different from the appropriate lean group at $\mathrm{p}<0.01$ fatty acid synthesis in adipose tissue of fa/fa rats had fallen dramatically by 13 weeks while hepatic lipogenesis was increased two-fold as compared to five week fa/fa rats. Serum insulin was increased in $\mathrm{fa} / \mathrm{fa}$ rats at 5 weeks, and increased further by 13 weeks.

As both the liver and adipose tissue pads were heavier in all fa/fa rats, the true increase in total lipogenesis in $\mathrm{fa} / \mathrm{fa}$ rats was even greater than that suggested by the differences in rate of fatty acid synthesis in Table 1. Even so, despite an increase in tissue weights, total fatty acid synthesis in both adipose depots fell with increasing age in fa/fa rats. The ratio of total fatty acid synthesised in liver and adipose tissue: (L:AT) was lower in $\mathrm{fa} / \mathrm{fa}$ rats at 5 weeks but had increased to a value above that of lean rats by 13 weeks.

Since the ${ }^{3} \mathrm{H}$-fatty acids extracted in adipose tissue could represent either de novo synthesis or fatty acids synthesized in the liver and subsequently transported to the adipose tissue during the time of the experiment, it was necessary to obtain some indication of the size of this hepatic contribution to adipose tissue ${ }^{3} \mathrm{H}$-fatty acids. The experiments were repeated in 'hepatectomized' rats. In such animals (Table 3), there was no significant incorporation of ${ }^{3} \mathrm{H}$ into hepatic lipids. Whereas the accumulation of ${ }^{3} \mathrm{H}$-fatty acid was similar in adipose tissue of lean control and 'hepatectomised' rats, $80-90 \%$ of the ${ }^{3} \mathrm{H}$ fatty acid in adipose tissue of $\mathrm{fa} / \mathrm{fa}$ rats was lost following 'hepatectomy', suggesting that hepatic secretion of ${ }^{3} \mathrm{H}$-fatty acids was a major source of the adipose tissue label. Both serum glucose and insulin were reduced by the method of 'hepatectomy' used to a similar degree in lean and $\mathrm{fa} / \mathrm{fa}$ rats.

Although no significant ${ }^{3} \mathrm{H}$ triglyceride fatty acids were observed in the serum of lean rats during the experimental time course (Fig. 2), the serum trigly-

Table 3. The contribution of hepatic fatty acids to the apparent adipose tissue lipogenesis in lean and obese fa/fa rats fed ad libitum

\begin{tabular}{|c|c|c|c|c|c|c|}
\hline & & \multicolumn{3}{|c|}{$\begin{array}{l}\text { Fatty acid synthesis } \\
(\mu \mathrm{mol} / \mathrm{tissue} / \mathrm{h})\end{array}$} & \multirow[t]{2}{*}{$\begin{array}{l}\text { Serum insulin } \\
(\mu U / \mathrm{ml})\end{array}$} & \multirow[t]{2}{*}{$\begin{array}{l}\text { Serum glucose } \\
(\mathrm{mmol} / \mathrm{l})\end{array}$} \\
\hline & & Hepatic & P. M. ${ }^{\mathrm{a}}$ & S. C. ${ }^{a}$ & & \\
\hline \multirow[t]{3}{*}{ Lean } & Control & $27.2 \pm 4.9$ & $1.7 \pm 0.3$ & $1.5 \pm 0.2$ & $64 \pm 5$ & $9.4 \pm 0.4$ \\
\hline & 'Hepatectomised' & N.D. & $1.5 \pm 0.5$ & $1.5 \pm 0.4$ & $31 \pm 4$ & $2.3 \pm 0.4$ \\
\hline & & $\mathrm{p}$ & N.S & N.S & $<.02$ & $<.001$ \\
\hline \multirow{3}{*}{$\mathrm{fa} / \mathrm{fa}$} & Control & $199.2 \pm 20.0$ & $41.4 \pm 11.7$ & $48.0 \pm 9.6^{\mathrm{c}}$ & $141 \pm 24$ & $9.5 \pm 0.3$ \\
\hline & 'Hepatectomised' & N.D. & $4.0 \pm 1.4$ & $6.8 \pm 2.0^{\mathrm{b}}$ & $57 \pm 5$ & $2.8 \pm 0.4$ \\
\hline & & $\mathrm{p}$ & $<0.05$ & $<0.05$ & $<.05$ & $<.001$ \\
\hline
\end{tabular}

\footnotetext{
a P.M. - perimetrial fat; S. C. - Subcutaneous fat. N. D. ${ }^{3} \mathrm{H}$ dpm in fatty acids could not be distinguished from background dpm. There were 6 animals in each group. After 'Hepatectomy' (see Methods), rats were immediately injected with ${ }^{3} \mathrm{H}_{2} \mathrm{O}$ and the accumulation of ${ }^{3} \mathrm{H}$ fatty acid measured after $60 \mathrm{~min}$

b $\mathrm{p}<0.05$

c $\mathrm{p}<0.001$ compared to appropriate lean group
} 


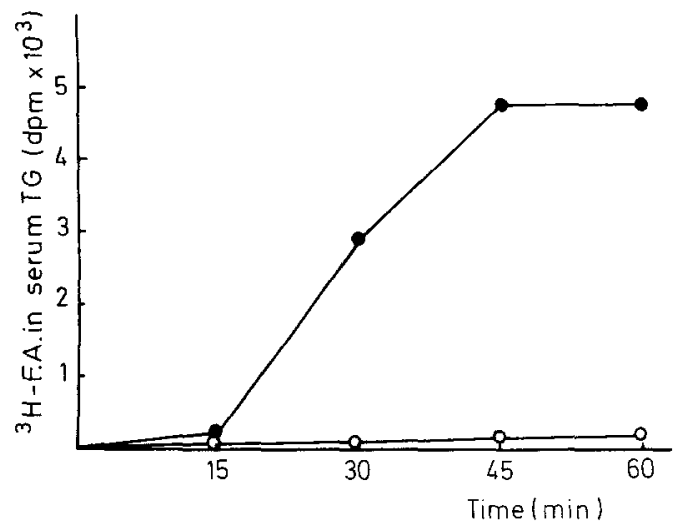

Fig. 2. Time course of the appearance of serum ${ }^{3} \mathrm{H}$-triglyceride fatty acids following the injection of ${ }^{3} \mathrm{H}_{2} \mathrm{O}$ into lean $(\mathrm{O})$ and $\mathrm{fa} / \mathrm{fa}$ (-) rats. Duplicate samples from a single rat were used for assay at each time point

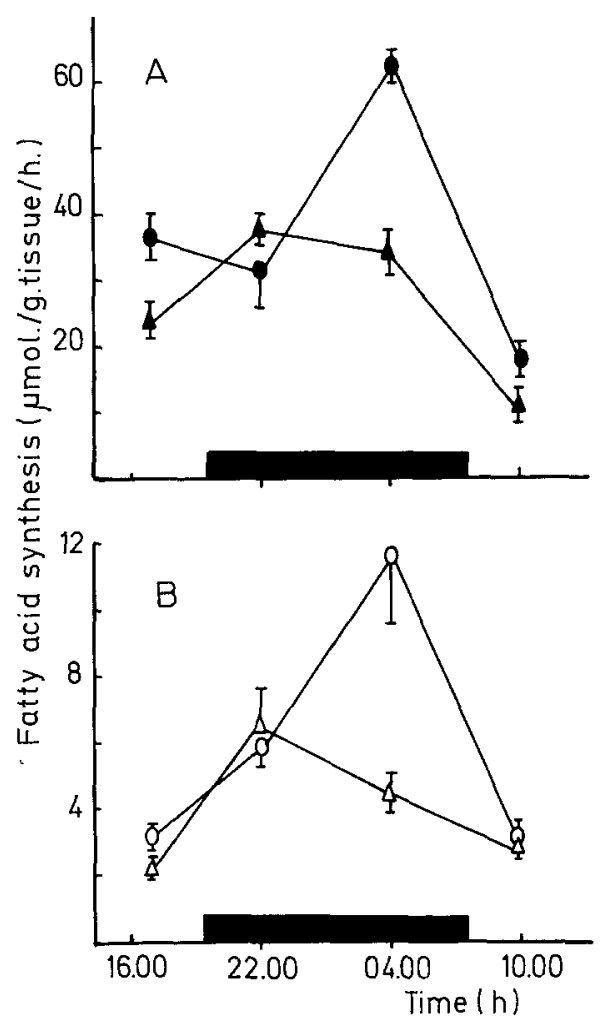

Fig. 3. Diurnal variation of lipogenesis in 6 week old lean and obese fa/fa rats. Lipogenesis in fa/fa (A) and lean (B) rats allowed free access to food was measured by the incorporation of ${ }^{3} \mathrm{H}_{2} \mathrm{O}$ into hepatic $(O, \bullet)$ and subcutaneous fat $(\triangle, \Delta)$. Values for perimetrial adipose tissue did not differ from subcutaneous fat and have been omitted. Three animals were used at each time

ceride of $\mathrm{fa} / \mathrm{fa}$ rats was rapidly labelled and reached a plateau by $45-60 \mathrm{~min}$. Further, the half-life of serum triglyceride, as measured by the fall of triglyceride after injection of Intralipid, was only $6.6 \pm 0.4 \mathrm{~min}$ in $\mathrm{fa} / \mathrm{fa}$ rats as compared to $11.5 \pm 0.5 \mathrm{~min}$ in lean rats.

All these experiments were performed between
Table 4, Fatty acid synthesis in obese fa/fa rats pair-fed to lean rats

\begin{tabular}{llrrl}
\hline \multirow{2}{*}{ Tissue } & \multicolumn{2}{c}{ Fatty acid synthesis } & $\begin{array}{l}\text { Serum insulin } \\
(\mu \mathrm{U} / \mathrm{ml})\end{array}$ \\
\cline { 3 - 4 } & & $(\mu \mathrm{mol} / \mathrm{g} / \mathrm{h})$ & $(\mu \mathrm{mol} /$ tissue/h $)$ & \\
\hline Lean & Hepatic & $9.2 \pm 1.4$ & $33.0 \pm 7.0$ & $154 \pm 66$ \\
& P.M. $^{\mathrm{a}}$ & $15.4 \pm 4.9$ & $4.9 \pm 1.0$ & \\
& S.C. & $7.0 \pm 1.1$ & $7.8 \pm 1.0$ & \\
fa/fa & Hepatic & $12.7 \pm 1.0$ & $54.2 \pm 3.0$ & $212 \pm 17$ \\
& P.M. & $10.2 \pm 3.9$ & $25.7 \pm 5.4$ & \\
& S.C. & $3.5 \pm 1.4$ & $23.6 \pm 6.8^{\mathrm{b}}$ & \\
\end{tabular}

a P.M. - perimetrial fat; S. C. - subcutaneous fat. All animals (6 per group) were pair fed for 2 weeks from 4 weeks of age on a meal-eating (4h) regime as described under Methods. ${ }^{3} \mathrm{H}_{2} \mathrm{O}$ was injected IV $2 \mathrm{~h}$ after the beginning of the feeding period, and the animals sacrificed $1 \mathrm{~h}$ later. Mean daily food intake was $8.3 \pm 0.3 \mathrm{~g} /$ day

b $\mathrm{p}<0.01$ compared to appropriate lean group

10.00 and 11.00 hours each day. Since the rat is nocturnal, it was interesting to study the diurnal variation in fatty acid synthesis (Fig. 3). As expected, both hepatic and adipose tissue fatty acid synthesis were greater in both lean and obese fa/fa rats during the dark period, although there was some divergence as to the actual time of peak lipogenesis. It is quite possible that peak lipogenesis may have occurred in both tissues at some time between the measurements at 2200 and 0400 hours.

Since lipogenesis is extremely sensitive to both the level of food intake and to circulating insulin, the next experiments were designed to investigate the importance of these two variables to the increase in lipogenesis. Table 4 shows the rate of lipogenesis of fa/fa rats pair-fed to lean rats for 14 days from 4 weeks of age. A meal feeding regime (4 hours daily) was used in these studies to prevent differences in feeding pattern. Animals were injected with ${ }^{3} \mathrm{H}_{2} \mathrm{O} 2$ hours after the beginning of feeding. Under these conditions both the serum insulin and the synthesis of fatty acid in all three sites were greatly enhanced in the lean rats (cf. Table 4 with Table 1 ). The serum insulin of $\mathrm{fa} / \mathrm{fa}$ rats was not significantly different from the lean rats three hours after the beginning of the feeding period. Furthermore, the rates of fatty acid synthesis in pair-fed fa/fa rats was reduced to or slightly below those rates seen in the lean rats. Nevertheless, the total synthesis of fatty acid remained higher in the $\mathrm{fa} / \mathrm{fa}$ rats because of the increased tissue sizes.

Streptozotocin treatment of weanling $\mathrm{fa} / \mathrm{fa}$ rats reduced the serum insulin level below that of ad libitum fed lean rats at both 5 and 13 weeks (Table 5). Hepatic fatty acid synthesis of streptozotocintreated $\mathrm{fa} / \mathrm{fa}$ rats was less than that in lean control rats. Similarly, the accumulation of ${ }^{3} \mathrm{H}$-fatty acids in 
Table 5. The effect of streptozotocin treatment on fatty acid synthesis in obese fa/fa rats

\begin{tabular}{lccccc}
\hline & \multicolumn{2}{l}{$\begin{array}{l}\text { Fatty acid synthesis } \\
(\mu \mathrm{mol} / \mathrm{g} / \mathrm{hr})\end{array}$} & & $\begin{array}{l}\text { Serum insulin } \\
(\mu \mathrm{U} / \mathrm{ml})\end{array}$ & $\begin{array}{l}\text { Weight gain } \\
(\mathrm{g} / \mathrm{d})\end{array}$ \\
\cline { 2 - 5 } 5 weeks & Hepatic & P. M..$^{\mathrm{a}}$ & $\mathrm{S.C}^{\mathrm{a}}$ & & \\
\hline Lean-control & $2.7 \pm 1.0$ & $1.4 \pm 0.1$ & $0.7 \pm 0.1$ & $56 \pm 5$ & $1.5 \pm 0.3$ \\
fa/fa-control & $26.5 \pm 1.0^{\mathrm{c}}$ & $10.6 \pm 1.1^{\mathrm{c}}$ & $7.6 \pm 0.4^{\mathrm{c}}$ & $164 \pm 22$ & $4.7 \pm 0.3$ \\
fa/fa-streptozotocin & $0.8 \pm 0.1^{\mathrm{e}}$ & $3.8 \pm 0.9^{\mathrm{d}}$ & $1.2 \pm 0.4^{\mathrm{e}}$ & $28 \pm 4^{\mathrm{e}}$ & $1.1 \pm 0.2$ \\
13 weeks & & & & \\
Lean-control & $4.8 \pm 1.5$ & $1.2 \pm 0.1$ & $1.1 \pm 0.3$ & $67 \pm 5$ & $1.1 \pm 0.2$ \\
fa/fa-control & $46.9 \pm 10.6^{\mathrm{c}}$ & $2.1 \pm 0.2^{\mathrm{b}}$ & $1.0 \pm 0.1$ & $319 \pm 22^{\mathrm{b}}$ & $4.6 \pm 0.8$ \\
fa/fa-streptozotocin & $2.4 \pm 0.5^{\mathrm{e}}$ & $0.3 \pm 0.1^{\mathrm{c}, \mathrm{e}}$ & $0.05 \pm 0.2$ & $55 \pm 2^{\mathrm{e}}$ & $1.5 \pm 0.4$ \\
\hline
\end{tabular}

a P.M. - perimetrial fat; S. C. - subcutaneous fat. Lipogenesis was measured 8 days after streptozotocin treatment. Lean control and fa/ fa control data is identical to that in Table 1. There were 6 animals in each group. Weight gain is that change between streptozotocin treatment and sacrifice at day 8

b $\mathrm{p}<0.01$ compared to lean control group

c $\mathrm{p}<0.001$ compared to lean control group

d $\mathrm{p}<0.01$ compared to fa/fa control

e $\mathrm{p}<0.001$ compared to fa/fa control

the two adipose depots was drastically reduced after streptozotocin treatment toward the values seen in the lean controls.

\section{Discussion}

The ${ }^{3} \mathrm{H}_{2} \mathrm{O}$ method for assay of lipogenesis is preferable to the use of ${ }^{14} \mathrm{C}$-labelled substrates because of the problems that might result from differing pool sizes between different groups of animals and variations of pool size during the course of an experiment. Furthermore, recent observations have shown that glucose does not provide a major source of carbon for hepatic lipogenesis in the rat $[12,18,19]$. We have recently confirmed this observation in isolated hepatocytes of fatty rats in which lactate is a major substrate for fatty acid synthesis [11]. Hence, a number of earlier observations made using ${ }^{14} \mathrm{C}$-labelled substrates require re-evaluation $[6,20]$. However, the quantitative estimation of fatty acid synthesis by the ${ }^{3} \mathrm{H}_{2} \mathrm{O}$ method assumes that the tissue marker rapidly equilibrates with the serum water to attain identical specific activities. Since it required 45-60 min for this equilibration, despite IV injection of ${ }^{3} \mathrm{H}_{2} \mathrm{O}$, the values for lipogenesis will be an underestimate of the true rates. However, a valid indication of the differences in lipogenesis between tissue sites and between animals is provided by this method since the rate of increase in tissue water specific activity was very similar in all three tissues in both animals. The rates of fatty acid synthesis observed in lean rats were very similar to other published values in situ and in perfused livers $[14,16,17]$.

Although the reported experiments were performed on anaesthetised rats, they clearly demon- strate the importance of the liver as a major site of fatty acid synthesis in the rat. Assuming that the fat depots investigated represent approximately one half of the total discrete adipose tissue stores, the ratio of lipogenesis in the liver and adipose tissue (L:AT) at 10.00 hours of lean rats becomes 3.7 at 5 weeks and falls to 3.0 at 13 weeks. Little transfer of ${ }^{3} \mathrm{H}$-fatty acid from the liver to adipose tissue was observed in lean rats during the time course of the experiments (see Table 3 and Fig. 2). These L:AT ratios are indicative of the predominant role that the liver plays in fatty acid synthesis in the rat. A similar conclusion has been reported for the lean mouse [12].

These reported studies would further suggest that the liver is primarily responsible for the excess fatty acid synthesis in both young ( 5 week) and mature (13 week) fa/fa rats. This conclusion results from the following observations. Although the L:AT ratio for fatty acid synthesis at 10.00 hours in 5 week fa/fa rats was only 2.0 (approximately 1.0 if it is assumed that only $50 \%$ of the adipose stores were analysed), the experiment with 'hepatectomized' rats indicated that the majority of the adipose tissue ${ }^{3} \mathrm{H}$-fatty acid had initially been synthesized in the liver. This conclusion is supported by the very rapid appearance of ${ }^{3} \mathrm{H}$-fatty acid in serum triglyceride in fa/fa rats and by the increase in turnover rate of serum triglyceride. After addition of this transported ${ }^{3} \mathrm{H}$-fatty acid fraction to the hepatic ${ }^{3} \mathrm{H}$-fatty acid, the $\mathrm{L}: \mathrm{AT}$ ratio for fatty acid synthesis in 5 week fa/fa rats rises to 26 . In quantitative terms, this represents a nine-fold increase in total hepatic lipogenesis in $\mathrm{fa} / \mathrm{fa}$ rats, as a result of both the increased rate (per gram) and the increase in liver size. These results confirm the suggestions made from studies of lipoprotein secretion 
$[9,21]$ and from ${ }^{14} \mathrm{C}$-acetate incorporation into tissue lipid [6] and from isolated hepatocyte studies $[10,11]$ that the liver is the major site of the extra lipogenesis in $\mathrm{fa} / \mathrm{fa}$ rats. Thus, the fa/fa rat clearly differs from the ob/ob mouse in which the adipose tissue is responsible for the major proportion of the excess lipogenesis [12]. It is possible that the low accumulation of ${ }^{3} \mathrm{H}$-fatty acid adipose tissue of fa/fa rats could partly be due to the fall in serum insulin and glucose levels during the experiment. However, similar falls in these variables in lean rats did not affect adipose tissue fatty acid synthesis during the 1 hour time course of the experiment.

Despite the dominance of hepatic lipogenesis, fatty acid synthesis in adipose tissue of fa/fa rats was also increased in young animals in confirmation of previous in vitro experimental reports $[3,7,8,22]$. Whereas the total fatty acid synthesised by adipose tissue increased with age in lean mice, it fell in $\mathrm{fa} / \mathrm{fa}$ rats despite both an increasing serum insulin level and an increased tissue mass. This indicates that the fall in the rate of fatty acid synthesis ( $\mu$ moles/gram tissue) in older fatty rats could not be attributed merely to the increased storage of triglycerides. From previous in vitro experiments, it was suggested that this fall in fatty acid synthesis might be attributable to the increasing insulin insensitivity of the adipose tissue of the fa/fa rats $[7,8,23]$. No such insensitivity was apparent in the liver of fa/fa rats.

It is possible from the available data on the diurnal variation in lipogenesis to calculate an approximate value for the total daily synthesis of fatty acids in these rats. At five weeks in lean rats this amounts to $763 \mu \mathrm{mol}(\sim 0.20 \mathrm{~g}$ fatty acid $)$ and in fa/fa rats to $9018 \mu \mathrm{mol}(\sim 2.38 \mathrm{~g}$ fatty acids). The fa/fa rat fed ad libitum may deposit fat at the rate of $2.7 \mathrm{~g} /$ day at this age with an excess storage of $2.3 \mathrm{~g} / \mathrm{d}$ when compared to lean littermates [24]. Thus, the calculated values, which do not allow for the catabolism of newly synthesized fatty acids, agree well with the rate of growth of the fatty rat.

Since the $\mathrm{fa} / \mathrm{fa}$ rat is both hyperphagic and hyperinsulinaemic $[2,23,25,26]$ the excessive lipogenesis in $\mathrm{fa} / \mathrm{fa}$ rats could be a result of these changes $[2,17,18,26]$, or be an independent primary expression of the gene defect. This latter suggestion would seem appropriate since an increase in body fat has been reported to occur prior to a detectable rise in insulin, the increase in food intake, or the decrease in activity [26, 27]. However, the demonstration that fatty acid synthesis (per gram tissue) in both liver and adipose tissue and serum insulin of $\mathrm{fa} / \mathrm{fa}$ rats were close to the levels in lean rats pair-fed on an identical meal eating regime suggests that the excess lipogenesis in $\mathrm{fa} / \mathrm{fa}$ rats is secondary to the hyper- phagia, hyperinsulinaemia and increased tissue mass. This conclusion was further supported by the suppression of lipogenesis in streptozotocin treated $\mathrm{fa} / \mathrm{fa}$ rats, but differs from that presented by Martin [6] who found that hepatic lipogenesis of pair-fed fa/fa rats was twice that of lean controls. The explanation of this difference may reside either in his use of much older $\mathrm{fa} / \mathrm{fa}$ rats or of ${ }^{14} \mathrm{C}$-acetate as a marker for lipogenesis. Further we have recently shown that the increase in hepatic lipogenesis in fatty rats does not occur until after weaning and may be prevented by delaying weaning. However body fat is already increased by that age, while body temperature is depressed suggesting that a defective thermogenesis may be the basis of the obesity in $\mathrm{fa} / \mathrm{fa}$ rats (Godbole, Bloxham and York, unpublished observations).

The authors are grateful to the M.R.C. for award of a project grant.

\section{References}

1. Zucker, T.F., Zucker, L. M.: Fat accretion and growth in the rat. J. Nutr. 80, 6-19 (1963)

2. Bray, G.A., York, D. A.: Genetically transmitted obesity in rodents. Physiol. Rev. 51, 598-646 (1971)

3. Bray, G. A., Barry, W.S., Mothon, S.: Lipogenesis in adipose tissue from genetically obese rats. Metabolism 19, 839-848 (1970)

4. Taketomi, S., Ishikawa, E., Iwatsuka, H.: Lipogenic enzymes in two types of genetically obese animals, fatty rats and yellow KK mice. Horm. Metab. Res. 7, 242-246 (1975)

5. Deb, S., Martin, R. J.: Effects of exercise and of food restriction on the development of spontaneous obesity in rats. J. Nutr. 105, 543-549 (1975)

6. Martin, R. J.: In vivo lipogenesis and enzyme levels in adipose and liver tissues from pair-fed genetically obese and lean rats. Life Sci. 14, 1447-1453 (1974)

7. York, D.A., Bray, G. A.: Adipose tissue metabolism in six week old fatty rats. Horm. Metab. Res. 5, 355-360 (1973)

8. York, D. A., Bray, G. A.: Genetic obesity in rats. II. The effect of food restriction on the metabolism of adipose tissue. Metabolism 22, 443-453 (1973)

9. Schonfeld, Y., Pfleger B.: Overproduction of very low density lipoproteins by livers of genetically obese rats. Am. J. Physiol. 226, 1178-1184 (1971)

10. Bloxham, D. P., York, D. A.: Metabolic flux through phosphofructokinase and fructose 1,6-Diphosphatase and its relation to lipogenesis in genetically obese rats. Biochem. Soc. Trans. 4, 989-993 (1977)

11. Bloxham, D.P., Fitzsimons, S., York, D. A.: Lipogenesis in hepatocytes of genetically obese rats. Horm. Metab. Res. 9, 304-309 (1977)

12. Hems, D. A., Rath, E. A., Verinder, T. R.: Fatty acid synthesis in liver and adipose tissue of normal and genetically obese $(\mathrm{ob} /$ ob) mice during the 24 hr cycle. Biochem. J. 150, 167-173 (1975)

13. Loten, E., Rabinovitch, A., Jeanrenaud, B.: In vivo studies on lipogenesis in obese hyperglycemic (ob/ob) mice. Possible role of hyperinsulinemia. Diabetologia 10, 45-52 (1974)

14. Lowenstein, J. M.: Effect of hydroxycitrate on fatty acid synthesis by rat liver in vivo. J. Biol. Chem. 246, 629-632 (1971) 
15. Folch, J., Lees, M., Sloane-Stanley, Y.N.: A simple method for the isolation and purification of total lipids from animal tissues. J. Biol. Chem. 226, 497-509 (1957)

16. Windmeuller, H., Spaeth, A. E.: Perfusion in situ with tritium oxide to measure hepatic lipogenesis and lipid secretion. J. Biol. Chem. 241, 2891-2899 (1966)

17. Windmeuller, H., Spaeth, A.E.: De novo synthesis of fatty acid in perfused rat liver as a determinant of plasma lipoprotein production. Arch. Biochem. Biophys. 122, 362-369 (1967)

18. Brunengraber, H., Boutry, M., Lowenstein, J.: Fatty acid and 3- $\alpha$-hydroxysterol synthesis in the perfused rat liver. J. Biol. Chem. 248, 2656-2659 (1973)

19. Clark, D., Rongstad, R., Katz, J.: Lipogenesis in rat hepatocytes. J. Biol. Chem. 269, 2028-2036 (1974)

20. Lemmonier, D., Aubert, R., Suquet, J.-P., Rosselin, G.: Metabolism of genetically obese rats on normal or high fat diet. Diabetologia 10, 697-701 (1974)

21. Schonfeld, Y., Felski, C., Howald, M.: Characterization of the plasma lipoproteins of the genetically obese-hyperlipoproteinemic Zucker fatty rat. J. Lipid Res. 15, 457-464 (1974)

22. Martin, R. J., Lamprey, P.: Early development of adipose cell lipogenesis and glycerol utilization in Zucker obese rats. Proc. Soc. Exp. Biol. Med. 149, 35-39 (1975)
23. Zucker, L. M., Antoniades, H. N.: Insulin and obesity in the Zucker genetically obese rat 'fatty'. Endocrinology 90, 1320-1330 (1972)

24. Zucker, L.M.: Efficiency of energy utilization by Zucker hereditarily obese rat 'fatty'. Proc. Soc. Exp. Biol. Med. 148, 498-500 (1975)

25. York, D. A., Steinke, J., Bray, G. A.: Hyperinsulinemia and insulin resistance in genetically obese rats. Metabolism 21, 277-284 (1972)

26. Dilettsuo, B., Wangsness, P.: Effect of age on hyperphagia of genetically obese Zucker rat. Proc. Soc. Exp. Biol. Med. 154, $1-5$ (1977)

27. Stern, J.S., Johnson, P. R.: Spontaneous activity and adipose cellularity in the genetically obese Zucker rat (fa/fa). Metabolism 26, 371-380 (1977)

Received: May 20, 1977

and in revised form: October 24, 1977

Dr. D. A. York

Department of Nutrition

School of Biochemical and Physiological Sciences

Southampton University

Southampton, SO9 3TU

England 